\title{
UTILIZAÇÃO DO RAMO E PROCESSO CORONÓIDE DA MANDÍBULA PARA A RECONSTRUÇÃO TOTAL DE MAXILA ATRÓFICA
}

Luiza NASCIMENTO, Fernando ANTONINI, Leandro KLUPPEL, Ricardo PASQUINI, Delson COSTA

Diversas fontes doadoras de enxerto ósseo estão disponíveis para reconstruções maxilares, diferenciando-se quanto as características embriológicas, tipo de osso, características físicas e morfológicas, volume de osso disponível, morbidade associada à remoção e taxa de reabsorção do enxerto. O presente trabalho visa demonstrar um caso clínico de reconstrução total de maxila atrófica com enxerto ósseo removido dos ramos e processos coronóides da mandíbula. Após remoção dos enxertos ósseos, a reconstrução óssea se deu com a instalação de 6 blocos em região anterior e parede lateral de maxila e acesso aos seios maxilares para preenchimento com osso autógeno particulado. Tal enxerto, além de evitar a remoção de enxertos ósseos de fontes extra-orais e consequentemente a morbidade associada a tal remoção, cumpriu os requisitos ideais dos enxertos ósseos, tais como baixa morbidade do sítio doador, mínima reabsorção, facilidade de remoção e alto componente de osso cortical. A cirurgia para a instalação de implantes dentários demonstrou boa incorporação do enxerto ósseo, com mínima reabsorção e principalmente promoção de volume ósseo suficiente para a instalação de 8 implantes dentários, sendo realizada 4 meses após a cirurgia reconstrutiva.

Palavras-chave: maxila atrófica; enxerto ósseo; implante. 